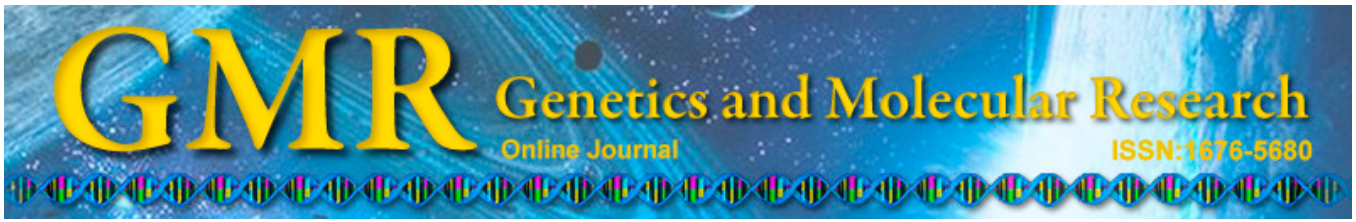

\title{
Identification and characterization of novel NBS-LRR resistance gene analogues from the pea
}

\author{
S. Djebbi ${ }^{1}$, D. Bouktila ${ }^{1,2}$, H. Makni ${ }^{1,3}$, M. Makni ${ }^{1}$ and \\ M. Mezghani-Khemakhem ${ }^{1}$ \\ ${ }^{1}$ Research Unit on Genomics of Crop Insect Pests, Department of Biology, \\ Faculty of Sciences of Tunis, University of Tunis El Manar, \\ Campus El Manar Tunis, Tunisia \\ ${ }^{2}$ University of Jendouba, Higher Institute of Biotechnology of Béja, Béja, Tunisia \\ ${ }^{3}$ University of Tunis, Higher Institute of Animation for Youth and Culture, \\ Bir El Bey, Tunisia \\ Corresponding author: M. Mezghani-Khemakhem \\ E-mail: mahakm@planet.tn
}

Genet. Mol. Res. 14 (2): 6419-6428 (2015)

Received July 14, 2014

Accepted January 21, 2015

Published June 11, 2015

DOI http://dx.doi.org/10.4238/2015.June.11.18

\begin{abstract}
Pea (Pisum sativum) is one of the most cultivated legumes in the world, and its yield and seed quality are affected by a variety of pathogens. In plants, NBS-LRR (nucleotide binding siteleucine-rich repeat) is the main class of disease resistance genes. Using degenerate primers deduced from conserved motifs in the NBS domain of known resistance genes, we identified 10 NBS sequences in three varieties of $P$. sativum. The deduced amino acid sequences of the identified resistance gene analogues (RGAs) exhibited the typical motifs of the NBS domain (P-loop, kinase-2, kinase-3a, and the hydrophobic domain, GLPL) present in the majority of plant proteins belonging to the NBS-LRR class. Phylogenetic analysis showed that seven RGAs belonged to the non-TIR-NBS-LRR subclass and three to the TIR-
\end{abstract}


NBS-LRR subclass. The results of this study provide insights into the structure of this class of resistance genes in the pea, and their evolutionary relationships with those of other plant species.

Key words: Pisum sativum; NBS-LRR; Disease resistance; Resistance gene analogues (RGAs)

\section{INTRODUCTION}

Pea (Pisum sativum L.) is an annual legume cultivated for its nutritional qualities and its ability to fix atmospheric nitrogen, which reduces the use of agricultural inputs. Several pests and diseases threaten pea production. Among these, fungal diseases caused by Fusarium wilt, Ascochyta blight, and powdery mildew are the most economically important in the Mediterranean basin region (Rubiales et al., 2009). Until now, several resistance genes (R genes) conferring resistance against many diseases and pests have been identified in the pea, such as Fw and Fwf for resistance to Fusarium wilt (Coyne et al., 2000; Okubara et al., 2005); er1, er2, and er3 against powdery mildew (Tiwari et al., 1997; Fondevilla et al., 2007); and Ppil, Ppi3, and Ppi4 that confer resistance against the pea bacterial blight disease caused by Pseudomonas syringae (Hunter et al., 2001). Despite the existence of well-known resistance genes in the pea, constant environmental changes and the adaptation of pathogens requires the investigation of germplasms, to identify new sources of resistance.

Most R genes identified so far belong to the NBS-LRR class that encodes protein receptors containing a nucleotide binding site (NBS) domain, and a C-terminal leucine-rich repeat domain (LRR) (Hulbert et al., 2001). Within the NBS-LRR class of plant R genes, two subclasses can be identified, according to the presence or absence of an N-terminal domain that is homologous to the Drosophila melanogaster Toll and the mammal interleukin-1 receptors (TIR), namely the TIR-NBS-LRR (TNL) and the non-TIR-NBS-LRR (non-TNL) subclasses, respectively (Pan et al., 2000). The non-TNL subclass commonly has a predicted coiled-coil structure (Pan et al., 2000).

The NBS domain is characteristic of various proteins, with GTP/ATP binding activity involved in signal transduction pathways (Traut, 1994), and is comprised of highly conserved and strictly ordered amino acid motifs, such as the P-loop, kinase-2, kinase-3a, and GLPL (Meyers et al., 1999). These motifs are maintained in the majority of characterized plant resistance genes, such as RPS2, RPM1, and RPP5 from Arabidopsis thaliana (Whalen et al., 1991; Grant et al., 1995), $N$ from tobacco (Whitham et al., 1995), $L 6$ and $M$ from flax (Lawrence et al., 1995; Anderson et al., 1997), $M i$ from tomato (Rossi et al., 1998), and Xal from rice (Yoshimura et al., 1998).

The highly conserved nature of the major motifs of the NBS domain has allowed the use of a degenerate oligonucleotide-primed polymerase chain reaction (PCR) strategy to identify homologous sequences called resistance gene analogues (RGAs) (Kanazin et al., 1996) or resistance gene candidates (Shen et al., 1998). Using this approach, several RGAs have been isolated from various species, including wheat (Zhang et al., 2011; Bouktila et al., 2014), A. thaliana (Meyers et al., 2003), faba bean and chickpea (Palomino et al., 2006), soybean (Graham et al., 2000), pea (Timmerman-Vaughan et al., 2000), and Medicago truncatula (Zhu et al., 2002). The identified RGAs correspond to different disease specificities, and, in some cases, their mapping has provided evidence that they co-segregate with resistance markers related 
to disease (Meyers et al., 1999). Some RGAs have also been used to develop molecular markers, in order to tag new disease resistance loci or quantitative trait loci (Kanazin et al., 1996; Leister et al., 1996; McHale et al., 2009; Song et al., 2012), and to identify resistant cultivars.

The aim of this study was to isolate new pea $\mathrm{R}$ gene analogues and determine their relationships among the pea RGAs and other cloned plant NBS-LRR-encoding R genes. These RGAs will be a valuable resource in pea breeding programs, particularly with regard to disease resistance traits.

\section{MATERIAL AND METHODS}

\section{Plant material}

The pea genotypes used in this study were provided by the National Institute of Agronomic Research of Tunisia (INRAT). These varieties were 'Spring pea 3', 'Rahma', and 'Yamama'. Total DNA was extracted from young leaf tissue of each variety, using the method described by Doyle and Doyle (1987). The quality of the DNA samples was examined by electrophoresis on $0.8 \%$ agarose gel, and their concentrations were measured with a NanoDrop ${ }^{\mathrm{TM}}$ Spectrophotometer (Thermo Scientific).

\section{PCR amplification of pea RGAs}

Four primer combinations designed from Glycine max (Kanazin et al., 1996) and Solanum tuberosum (Leister et al., 1996) were used to tentatively isolate novel NBS-encoding sequences from the pea. The forward primers were designed from the P-loop and the reverse primers from the hydrophobic domain of NBS resistance genes. These primer sets were predicted to amplify a PCR product of around $500 \mathrm{bp}$ in length (Table 1). PCRs were conducted in a total volume of $25 \mu \mathrm{L}$ containing $600 \mathrm{ng}$ DNA, $10 \mathrm{pmol}$ of each primer, 5X PCR buffer, 25 $\mathrm{mM} \mathrm{MgCl}, 10 \mathrm{mM}$ dNTPs, and $1 \mathrm{U}$ GoTaq DNA polymerase (Promega). The PCR program included an initial denaturation step at $94^{\circ} \mathrm{C}$ for $2 \mathrm{~min}$, followed by 40 cycles at $94^{\circ} \mathrm{C}$ for 45 $\mathrm{s}, 45^{\circ} \mathrm{C}$ for $45 \mathrm{~s}, 72^{\circ} \mathrm{C}$ for $1 \mathrm{~min}$, and a final extension at $72^{\circ} \mathrm{C}$ for $8 \mathrm{~min}$. The amplification products were visualized by electrophoresis on $1 \%$ agarose gel.

Table 1. Degenerate primers used to amplify nucleotide-binding site sequences from three pea varieties.

\begin{tabular}{llll}
\hline Primer code & Target sequence & Primer sequence (5' to 3')* & Reference \\
\hline s1 & P-loop (GGVGKTT) & GGTGGGGTTGGGAAGACAACG & Leister et al., 1996 \\
s2 & Hydrophobic domain (GLPL) & GGIGGIGTIGGIAAIACIAC & CAACGCTAGTGGCAATCC \\
as1 & & ARIGCTARIGGIARICC & Kanazin et al., 1996 \\
as4 & & \\
\hline
\end{tabular}

*IUPAC standard codes of mixed bases. $\mathrm{I}=\mathrm{A} / \mathrm{C} / \mathrm{T}$.

\section{Cloning and sequencing of the PCR products}

Eight PCR products of approximately $500 \mathrm{bp}$ in length were excised from the agarose gel, and DNA samples were retrieved from the gel slices using a Wizard ${ }^{\circledR}$ SV Gel and PCR Clean-Up System (Promega), following the manufacturer protocol. PCR-recovered products 
were cloned into a pGEM ${ }^{\circledR}$-T Easy Vector System (Promega) and transformed into competent Escherichia coli DH5a (NEB). Ten positive clones, representative of each band, were randomly selected, and the recombinant plasmids were extracted using a Plasmid DNA Purification Miniprep Kit (Promega), and were later sequenced using a T7 universal primer.

\section{Sequence alignment and phylogenetic analysis}

An homology search was performed using BLAST 2.2.27+ (Altschul et al., 1997) at the web page of the National Center of Biotechnology Information (http://www.ncbi.nlm. nih.gov/blast/Blast.cgi?CMD=Web\&PAGE_TYPE=BlastHome). The nucleotide sequences were translated using GeneDoc (version 2.7.000), and the deduced amino acid sequences were aligned to investigate the conserved motifs. The MEGA (version 5.05) software (Tamura et al., 2011) was used to estimate the genetic distance between the pea RGAs and other plants' RGAs and $\mathrm{R}$ genes, and to reconstruct their phylogenetic relationships using the unweighted pair group method with arithmetic mean (UPGMA) method.

\section{RESULTS}

\section{Homology searches}

PCR products of the expected size $(\sim 500 \mathrm{bp})$ were generated by each of the four primer sets with the pea varieties 'Spring pea 3', 'Rahma', and 'Yamama' (Figure 1). Primer sets I and II each generated two major bands of around $500 \mathrm{bp}$ and $300 \mathrm{bp}$, respectively, in size, and a few faint bands. Primer set III produced a major band of $550 \mathrm{bp}$ and a few faint bands that ranged from 100 to $250 \mathrm{bp}$ in size. Primer set IV only amplified a PCR product of about $500 \mathrm{bp}$ in size. Therefore, PCR products of $500 \mathrm{bp}$ in length were generated by primer sets I and II, and those of $550 \mathrm{bp}$ in length obtained by primer sets III and IV were cloned separately from each pea variety. Ten recombinant (white) clones from each ligation reaction were randomly chosen to be further characterized by sequencing. BLAST searches revealed that only 17 sequences had similarities to NBS sequences, while the remaining sequences were either retrotransposon-like sequences or did not exhibit any significant similarities to any of the publicly available proteins. Of the 17 NBS-like clones, only 10 (that were non-redundant) were retained, and were labeled RGA1 to RGA10 (Table 2).

Primer set IV was the most successful, as it provided seven out of the total 10 NBSencoding sequences from all of the tested varieties. Primer sets II and III each generated two RGA sequences from 'Rahma' and 'Yamama', respectively, while primer set I yielded a unique NBS sequence from 'Spring pea 3' (Table 2).

Homology searches of the GenBank database revealed that the obtained NBS sequences exhibited significant similarities with three previously identified RGAs: RGAGA3 (AAD52719.1) and RGA1.1 (AAD52711.1) from pea, and RGA (CAD56810.1) from a Lens cultivar resistant to race 6 of $P$. syringae (Table 2). The identities assigned to the identified NBS sequences fell into three categories: the first category included RGAs with a perfect identity (RGA1), the second group included RGAs with an identity of between 90 and $100 \%$ (RGA2-8), and the third group included RGAs with an identity lower than $80 \%$ (RGA9 and RGA10). This arrangement displays the discovery of 9 new RGAs of the identified RGAs. 


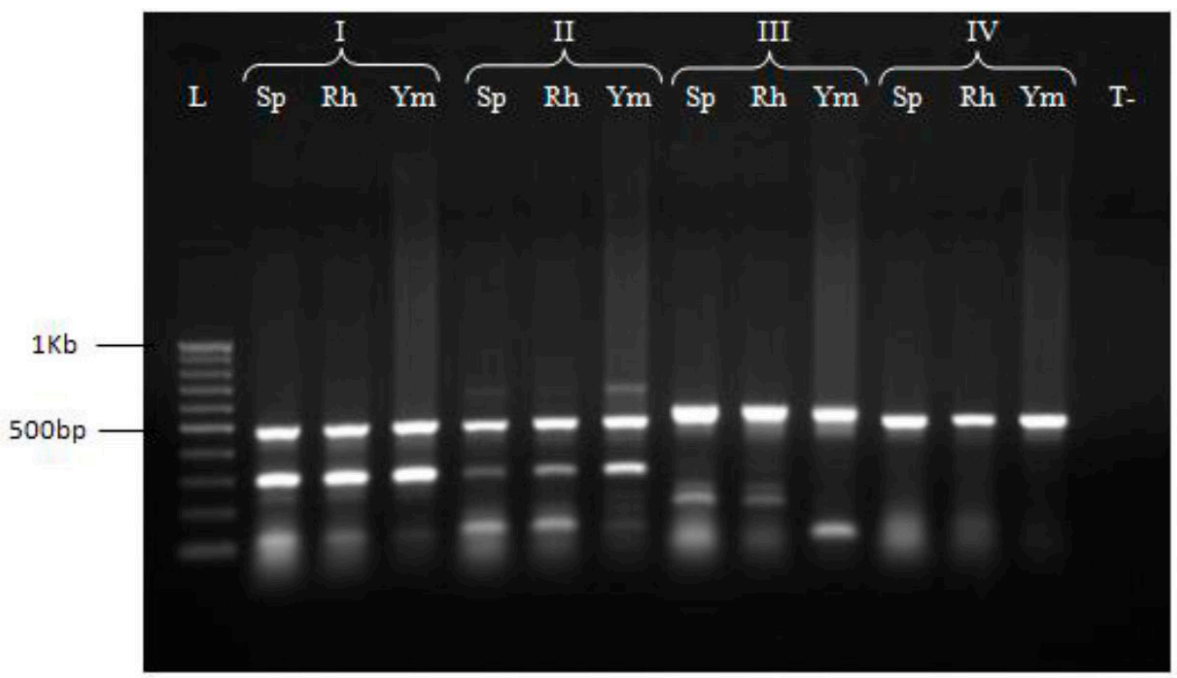

Figure 1. Polymerase chain reaction products amplified from the genomic DNA of different pea varieties, using four primer sets: lanes $I=\mathrm{s} 1 / \mathrm{as} 1$; lanes $I I=\mathrm{s} 1 / \mathrm{as} 4$; lanes $I I I=\mathrm{s} 2 / \mathrm{as} 1$; and lanes $I V$, s2/as4. The varieties were: $\mathrm{Sp}$, 'Spring pea 3'; Rh, 'Rahma', and Ym, 'Yamama'. Lane L= 1 kb (Invitrogen).

Table 2. Results of similarity searches between resistance gene analogues (RGAs) isolated from three pea varieties and all publicly available proteins from the National Center for Biotechnology Information, using BLASTx (Altschul et al., 1997).

\begin{tabular}{|c|c|c|c|c|c|c|c|}
\hline $\begin{array}{l}\text { Identified RGA } \\
\text { used as a query }\end{array}$ & $\begin{array}{c}\text { Primer } \\
\text { combination }\end{array}$ & Variety & $\begin{array}{c}\text { RGA } \\
\text { length (bp) }\end{array}$ & $\begin{array}{l}\text { RGA accession } \\
\text { No. }\end{array}$ & BLASTx best hits & $\begin{array}{l}\text { Amino acid } \\
\text { identity }(\%)\end{array}$ & E value \\
\hline RGA1 & $\begin{array}{c}\text { I } \\
\text { II } \\
\text { III }\end{array}$ & $\begin{array}{l}\mathrm{Sp} \\
\mathrm{Rh} \\
\mathrm{Ym}\end{array}$ & 541 & JX854542 & $\begin{array}{l}\text { Putative NBS-LRR-type disease } \\
\text { resistance protein (Pisum sativum) } \\
\text { AAD52711.1 }\end{array}$ & 100 & $9 e-109$ \\
\hline RGA2 & IV & $\mathrm{Rh}$ & 510 & JX854549 & $\begin{array}{l}\text { Putative NBS-LRR-type disease } \\
\text { resistance protein (Pisum sativum) } \\
\text { AAD52719.1 }\end{array}$ & 99 & $2 e-109$ \\
\hline RGA3 & IV & $\mathrm{Ym}$ & 509 & KC633409 & $\begin{array}{l}\text { Putative NBS-LRR-type disease } \\
\text { resistance protein (Pisum sativum) } \\
\text { AAD52719.1 }\end{array}$ & 99 & $5 e-110$ \\
\hline RGA4 & II & $\mathrm{Rh}$ & 541 & JX854544 & $\begin{array}{l}\text { Putative NBS-LRR-type disease } \\
\text { resistance protein (Pisum sativum) } \\
\text { AAD52711.1 }\end{array}$ & 99 & $3 e-108$ \\
\hline RGA5 & III & Ym & 540 & KC633408 & $\begin{array}{l}\text { Putative NBS-LRR-type disease } \\
\text { resistance protein (Pisum sativum) } \\
\text { AAD52711.1 }\end{array}$ & 99 & $1 e-107$ \\
\hline RGA6 & IV & $\mathrm{Sp}$ & 510 & JX854546 & $\begin{array}{l}\text { Putative NBS-LRR-type disease } \\
\text { resistance protein (Pisum sativum) } \\
\text { AAD52719.1 }\end{array}$ & 92 & $3 e-93$ \\
\hline RGA7 & IV & $\mathrm{Rh}$ & 510 & JX854550 & $\begin{array}{l}\text { Putative NBS-LRR-type disease } \\
\text { resistance protein (Pisum sativum) } \\
\text { AAD52719.1 }\end{array}$ & 99 & $2 e-109$ \\
\hline RGA8 & IV & Ym & 509 & KC633410 & $\begin{array}{l}\text { Putative NBS-LRR-type disease } \\
\text { resistance protein (Pisum sativum) } \\
\text { AAD52719.1 }\end{array}$ & 99 & $3 e-109$ \\
\hline RGA9 & IV & $\mathrm{Sp}$ & 513 & JX854547 & $\begin{array}{l}\text { Putative resistance gene analogue } \\
\text { protein (Lens culinaris) CAD56810.1 }\end{array}$ & 84 & $8 e-96$ \\
\hline RGA10 & IV & $\mathrm{Sp}$ & 513 & JX854548 & $\begin{array}{l}\text { Putative resistance gene analogue } \\
\text { protein (Lens culinaris) CAD56810.1 }\end{array}$ & 85 & $5 e-96$ \\
\hline
\end{tabular}




\section{Motif structure analysis}

The 10 RGA sequences obtained were translated, and amino acid alignments showed the typical consensus motifs (P-loop, kinase-2a, kinase3, and GLPL) of NBS-LRR R genes (Figure 2). The NBS domain of RGA1 and RGA4-5, obtained with primer sets I, II, and III, showed an RNBS-A-TIR motif (consensus FLENIREXSKKHGLEHLQKKLLSKLL), as well as a tryptophan $(\mathrm{W})$ residue at the end of the kinase- 2 motif, both of which are associated with non-TIR-NBS subclass sequences (Meyers et al., 2002).

The remaining RGAs (RGAs2-3 and RGAs6-10), all generated by primer set IV, lacked the previously described characteristics, and instead exhibited the TIR-NBS motifs determined by Bai et al. (2002).

Although the presence of aspartic acid (D) at the last position of the same motif is characteristic of the TIR-NBS-LRR subclass (Bai et al., 2002), this amino acid was present only in RGAs2-3 and RGAs6-8, and was substituted by a glycine (G) residue in RGAs9-10.

For all of the RGA sequences, the P-loop motif (GGVGKTT) and the hydrophobic motif (GLPL), from which sense and anti-sense primers were designated, were highly conserved. The two internal motifs, kinase-2a and kinase3, exhibited variations in their sequences; the consensus sequence of the kinase-2a motif was present in four versions: LFVLDDIW, LVFLDNV, LIILDNV, or LVVLDNV; and the kinase-3 motif was present in three versions: GSMVIITTR, GSRIIIISR, or RSRIIIISR (Figure 2).

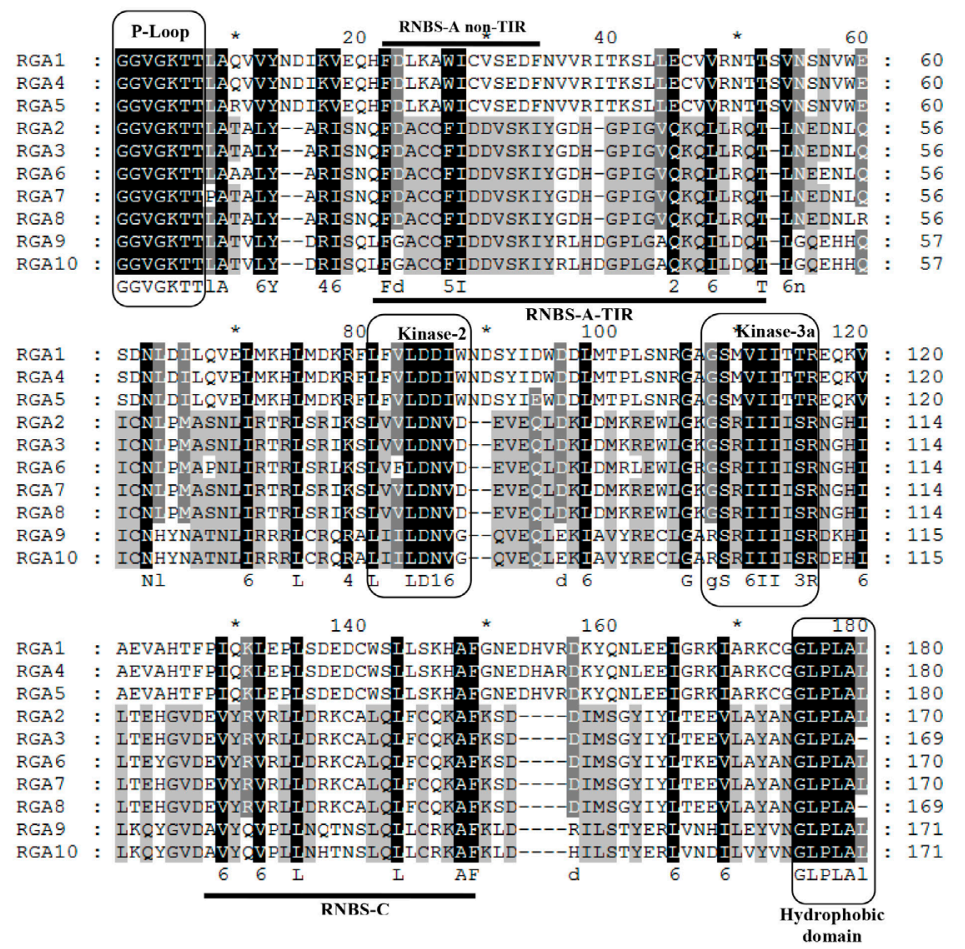

Figure 2. Amino acid alignments of 10 nucleotide binding site-type resistance gene analogues (RGAs) (RGA1 to RGA10) isolated from three pea varieties. 


\section{Phylogenetic analysis}

Phylogenetic analysis was performed on the pea RGA sequences identified in this study. For this purpose, we included nine pea RGAs previously identified by TimmermanVaughan et al. (2000), as well as reference R genes belonging to subclasses TIR and non-TIR $\mathrm{R}$ proteins. Based on multiple alignments of amino acid sequences, an UPGMA tree was constructed. The phylogenetic tree grouped RGA1 and RGAs4-5 with the non-TIR subclass and RGAs2-3 and RGAs6-10 with the TIR subclass (Figure 3).

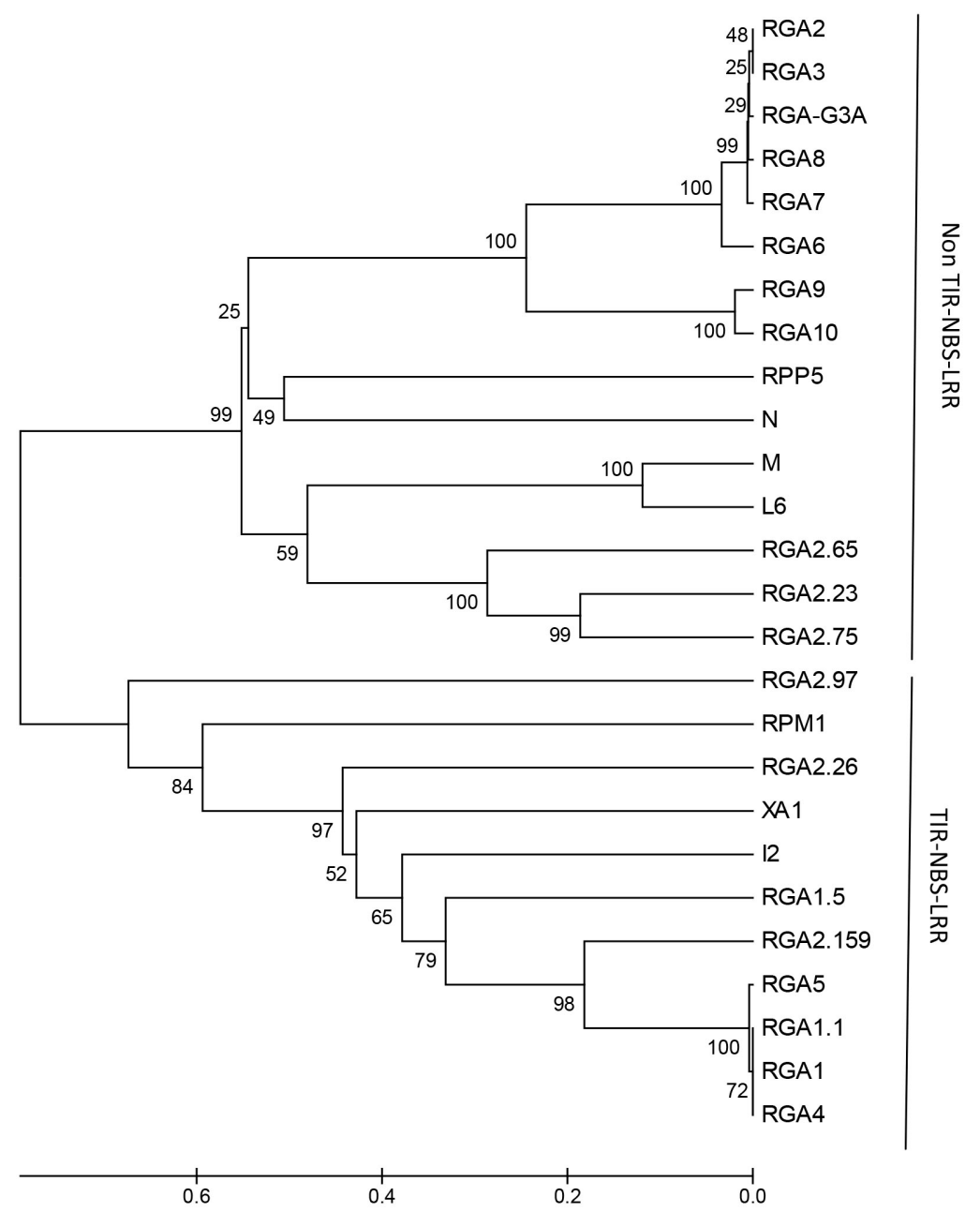

Figure 3. Phylogenetic tree inferred from protein sequences, showing similarity between 10 identified pea resistance gene analogs (RGAs) (RGA1 to RGA10) and nucleotide binding site domains of reference R genes, from tomato (I2), rice (Xa1), Arabidopsis thaliana (RPP5 and RPM1), tobacco $(N)$, and Linum usitatissimum (M and LO). The following previously identified pea RGAs (Timmerman-Vaughan et al., 2000) were included in the analysis: TIRNBS: RGA2.97 (AAD52717.1), RGA2.26 (AAD52714.1), RGA1.5 (AAD52712.1), RGA2.159 (AAD52718.1), and RGA1.1 (AAD52711.1); and non-TIR-NBS: RGA-GA3 (AAD52719.1), RGA2.65 (AAD52715.1), RGA2.23 (AAD52713.1), and GA2.75 (AAD52716.1). 


\section{DISCUSSION}

Using degenerate primers to isolate resistance gene analogs from different plant species has so far been an effective strategy (Yaish et al., 2004; Palomino et al., 2006; Bouktila et al., 2014). In the present study, we identified and characterized 10 RGAs in three pea varieties, using four primer combinations designated from G. $\max$ (Kanazin et al., 1996) and $S$. tuberosum (Leister et al., 1996).

Primer set IV was the most effective, since it enabled the identification of most (7/10) of the RGAs obtained from the three pea varieties. This primer set has previously allowed the isolation of eight RGAs from two other pea varieties (Timmerman-Vaughan et al., 2000) and three RGAs from the lentil (Yaish et al., 2004). However, additional studies conducted on the faba bean and chickpea have found that set III is more efficient, as it allowed the identification of 55 RGAs among the 149 isolated from these two Fabaceae species (Palomino et al., 2006).

In our study, retrotransposon-like sequences were obtained by primer set II due to their ubiquitous dispersion in plant genomes, and their roles in adaptation to biotic and abiotic stress. Indeed, previous studies have revealed the predominance of mobile elements and DNA repeats in the pea genome (Macas et al., 2007). The RGAs identified from P. sativum exhibited the typical motif architecture of the NBS-LRR class, with a common diversification into TIR and non-TIR subfamilies, as has been reported in dicotyledones (Marone et al., 2013). The phylogenetic analysis, conducted using the UPGMA method, supported the classification of our pea RGAs into TIR and non-TIR subclasses, since they were clustered close to other pea or non-pea NBS sequences of both these subclasses.

Both TIR-NBS-LRR and non-TIR-NBS-LRR subclasses have been cloned from plants; however, the ratio of these two subclasses is variable across species. In this study, of the 10 RGAs identified, seven were characterized as belonging to the non-TIR-NBS-LRR subclass. In contrast, relatively more TIR-NBS class RGAs have been reported in the cowpea (Bhavani et al., 2002), lentil (Yaish et al., 2004), and soybean (Kanazin et al. 1996).

An equal distribution of the two subclasses has been reported in the genome of the model legume $M$. truncatula, both non-TIR-NBS-LRR and 156 TIR-NBS-LRR proteins (Ameline-Torregrosa et al., 2008). For P. sativum, the present lack of a reference genome sequence, which is currently in progress, prevents the reporting of the precise distribution of these two subclasses in this legume.

The functional assignment of our identified RGAs remains approximate, as it is based on BLAST and phylogeny proofs. Therefore, we can conclude that the high similarity between the 10 pea NBS RGAs identified and those of Lens culinaris supports the hypothesis that this class of resistance genes is highly conserved within the legumes. In addition, the phylogenetic tree revealed that the non-TIR pea RGAs reported here (RGA1 and RGAs4-5) exhibited a high homology with pea RGA1.1 (AAD52711.1), which has been mapped on a linkage group containing a dominant gene for resistance to Fusarium wilt $(F w)$ (Timmerman-Vaughan et al., 2000). Instead, the seven TIR-NBS pea RGAs identified in our study (RGAs2-3 and RGAs610) were highly homologous to RGA-G3A (AAD52719.1), which was previously mapped on a linkage group containing genes involved in rhizobia-plant symbiosis (Timmerman-Vaughan e al., 2000). This suggests that the 10 pea RGAs isolated in this study might be involved in conferring resistance against either fungal or bacterial pea pathogens.

In conclusion, the present study identified a total of 10 RGAs in the pea genome, nine of which are unique sequences. Motif structure, as well phylogenetic inference, enabled the 
categorization of sequences into TIR and non-TIR subclasses. The RGAs identified were tentatively characterized based on their similarities to functionally assigned sequences. The continued isolation and analysis of new NBS sequences from different pea genotypes will provide a strong framework towards a better understanding of their molecular evolution and their potential use in breeding programs, in order to incorporate novel resistance sources into cultivated varieties.

\section{ACKNOWLEDGMENTS}

We thank Sonia Boukhris-Bouhachem and Mohamed Kharrat of the National Institute of Agronomic Research of Tunisia (INRAT, Tunis, Tunisia) for providing the pea cultivars ('Rahma', 'Spring pea 3', and 'Yamama'). Research supported by the Tunisian Ministry of Higher Education and Scientific Research.

\section{REFERENCES}

Altschul SF, Madden TL, Schaffer AA, Zhang J, et al. (1997). Gapped BLAST and PSI-BLAST: a new generation of protein database search programs. Nucleic Acids Res. 25: 3389-3402

Ameline-Torregrosa C, Wang BB, O’Bleness MS, Deshpande S, et al. (2008). Identification and characterization of nucleotide-binding site-leucine-rich repeat genes in the model plant Medicago truncatula. Plant Physiol. 146: 5-21.

Anderson PA, Lawrence GJ, Morrish BC, Ayliffe MA, et al. (1997). Inactivation of the flax rust resistance gene $M$ associated with loss of a repeated unit within the leucine rich repeat coding region. Plant Cell 9: 641-651.

Bai J, Pennill LA, Ning J, Lee SW, et al. (2002). Diversity in nucleotide binding site-leucine-rich repeat genes in cereals. Genome Res. 12: 1871-1884

Bhavani SG, Jennifer LM, Sarah SR, Dilram RS, et al. (2002). Isolation, sequence analysis, and linkage mapping of resistance-gene analogs in cowpea (Vigna unguiculata L. Walp.). Euphytica 126: 365-377.

Bouktila D, Habachi-Houimli Y, Khalfallah Y, Mezghani-Khemakhem M, et al. (2014). Characterization of novel wheat NBS domain containing sequences and their utilization, in silico, for genome scale $R$ gene mining. Mol. Genet. Genomics 289: 599-613.

Coyne CJ, Inglis DA, Whitehead SJ, Muehlbauer FJ, et al. (2000). Chromosomal location of Fwf in pea. Pisum Genet. 32: $20-22$.

Doyle JJ and Doyle JL (1987). A rapid DNA isolation procedure for small quantities of fresh leaf tissue. Photochem. Bull. 19: 11-15.

Fondevilla S, Torres AM, Moreno MT and Rubiales D (2007). Identification of a new gene for resistance to powdery mildew in Pisum fulvum, a wild relative of pea. Breeding Sci. 57: 181-184.

Graham MA, Fredrick Marek L, Lohnes D, Cregan P, et al. (2000). Expression and genome organization of resistance gene analogs in soybean. Genome 43: 86-93.

Grant MR, Godiard L, Straube E, Ashfield T, et al. (1995). Structure of the Arabidopsis RPM1 gene enabling dual specificity disease resistance. Science 269: 843-846.

Hulbert SH, Webb CA, Smith SM and Sun Q (2001). Resistance gene complexes: evolution and utilization. Annu. Rev. Phytopathol. 39: 285-312.

Hunter PJ, Ellis N and Taylor JD (2001). Association of dominant loci for resistance to Pseudomonas syringae pv. pisi with linkage groups II, VI and VII of Pisum sativum. Theor. Appl. Genet. 103: 129-135.

Kanazin V, Marek LF and Shoemaker RC (1996). Resistance gene analogs are conserved and clustered in soybean. Proc. Natl. Acad. Sci. U. S. A. 93: 11746-11750.

Lawrence GJ, Finnegan EJ, Ayliffe MA and Ellis JG (1995). The L6 gene for flax rust resistance is related to the Arabidopsis bacterial resistance gene RPSP and the tobacco viral resistance gene N. Plant Cell 7: 1195-1206.

Leister D, Ballvora A, Salamini F and Gebhardt C (1996). A PCR based approach for isolating pathogen resistance genes from potato with potential for wide application in plants. Nature Genet. 14: 421-429.

Macas J, Neumann P and Navrátilová A (2007). Repetitive DNA in the pea (Pisum sativum L.) genome: comprehensive characterization using 454 sequencing and comparison to soybean and Medicago truncatula. BMC Genom. 8: 427.

Marone D, Russo MA, Laidò G, De Leonardis AM, et al. (2013). Plant nucleotide binding site-leucine-rich repeat (NBSLRR) genes: active guardians in host defense responses. Int. J. Mol. Sci. 14: 7302-7326. 
McHale LK, Truco MJ, Kozik A, Wroblewski T, et al. (2009). The genomic architecture of disease resistance in lettuce. Theor. Appl. Genet. 118: 565-580.

Meyers BC, Kozik A, Griego A, Kuang H, et al. (2003). Genome-wide analysis of NBS-LRR-encoding genes in Arabidopsis. Plant Cell 15: 809-834.

Meyers BC, Dickerman AW, Michelmore RW, Sivaramakrishnan S, et al. (1999). Plant disease resistance genes encode members of an ancient and diverse protein family within the nucleotide-binding superfamily. Plant J. 20: 317-322.

Meyers BC, Morgante M and Michelmore RW (2002). TIR-X and TIR-NBS proteins: two new families related to disease resistance TIR-NBS-LRR proteins encoded in Arabidopsis and other plant genomes. Plant J. 32: 77-92.

Okubara PA, Keller KE, McClendon MT, McPhee KE, et al. (2005). Y15_999Fw, a dominant SCAR marker linked to the Fusarium wilt race $1(\mathrm{Fw})$ resistance gene in pea. Pisum Genet. 37: 32-35.

Palomino C, Satovic Z, Cubero JI and Torres AM (2006). Identification and characterization of NBS-LRR class resistance gene analogs in faba bean (Vicia faba L.) and chickpea (Cicer arietinum L.). Genome 49: 1227-1237.

Pan Q, Wendel J and Fluhr R (2000). Divergent evolution of Plant NBS-LRR resistance gene homologues in dicot and cereal genomes. J. Mol. Evol. 50: 203-213.

Rossi M, Goggin FL, Milligan SB, Kaloshian I, et al. (1998). The nematode resistance gene Mi of tomato confers resistance against the potato aphid. Proc. Natl. Acad. Sci. U. S. A. 95: 9750-9754.

Rubiales D, Fernandez-Aparicio M, Moral A, Barilli E, et al. (2009). Disease resistance in pea (Pisum sativum L.) types for autumn sowings in Mediterranean environments. Czech J Genet. Plant Breed. 45: 135-142.

Shen KA, Meyers BC, Islam-Faridi MN, Chin DB, et al. (1998). Resistance gene candidates identified by PCR with degenerate oligonucleotide primers map to clusters of resistance genes in lettuce. Am. Phytopathol. Soc. 11: 815-823.

Song X, Deng Z, Gong L, Hu J, et al. (2012). Cloning and characterization of resistance gene candidate sequences and molecular marker development in gerbera (Gerbera hybrida). Sci. Hortic. Amsterdam 145: 68-75.

Tamura K, Peterson D, Peterson N, Stecher G, et al. (2011). MEGA5: molecular evolutionary genetics analysis using maximum likelihood, evolutionary distance, and maximum parsimony methods. Mol. Biol. Evol. 28: 2731-2739.

Timmerman-Vaughan GM, Frew TJ and Weeden NF (2000). Characterization and linkage mapping of R-gene analogous DNA sequences in pea (Pisum sativum L.). Theor. Appl. Genet. 101: 241-247.

Tiwari KR, Penner GA and Warkentin TD (1997). Inheritance of powdery mildew resistance in pea. Can. J. Plant Sci. 36: $1-5$.

Traut TW (1994). The function and consensus motifs of nine peptide segments that form different types of nucleotidebinding sites. Eur. J. Biochem. 222: 9-19.

Whalen MC, Innes RW, Bent AF and Staskawicz BJ (1991). Identification of Pseudomonas syringae pathogens of Arabidopsis and a bacterial locus determining avirulence on both Arabidopsis and soybean. Plant Cell 3: 49-59.

Whitham S, Dinesh-Kumar SP, Choi D, Hehl R, et al. (1995). The product of the tobacco mosaic virus resistance gene $N$ : similarity to toll and the interleukin-1 receptor. Cell 81: 1101-1115.

Yaish MWF, Saenz De Miera LE and Perez De La Vega M (2004). Isolation of a family of resistance gene analogue sequences of the nucleotide binding site (NBS) type from Lens species. Genome 47: 650-659.

Yoshimura S, Yamanouchi U, Katayose Y, Toki S, et al. (1998). Expression of Xa1, a bacterial blight resistance gene in rice, is induced by bacterial inoculation. Proc. Natl. Acad. Sci. U. S. A. 95: 1663-1668.

Zhang N, Wang S, Wang H and Liu D (2011). Isolation and characterization of NBS-LRR class resistance homologous gene from wheat. Agr. Sci. China 10: 1151-1158.

Zhu H, Cannon SB, Young ND and Cook DR (2002). Phylogeny and genomic organization of the TIR and non-TIR-NBSLRR resistance gene family in Medicago truncatula. Mol. Plant Microbe In. 15: 529-539. 